\title{
Developing recombinant HPA-1a-specific antibodies with abrogated Fc $\gamma$ receptor binding for the treatment of fetomaternal alloimmune thrombocytopenia
}

\author{
Cedric Ghevaert, 1,2 David A. Wilcox,3,4,5 Juan Fang,3,4 Kathryn L. Armour, ${ }^{6}$ \\ Mike R. Clark, ${ }^{6}$ Willem H. Ouwehand, ${ }^{1,2}$ and Lorna M. Williamson ${ }^{1,2}$
}

\begin{abstract}
${ }^{1} \mathrm{NHS}$ Blood and Transplant, Cambridge, United Kingdom. ${ }^{2}$ Department of Haematology, University of Cambridge, Cambridge, United Kingdom. ${ }^{3}$ Department of Pediatrics, Medical College of Wisconsin, Milwaukee, Wisconsin, USA. ${ }^{4}$ Children's Research Institute, Children's Hospital of Wisconsin, Milwaukee, Wisconsin, USA. ${ }^{5}$ Blood Research Institute, BloodCenter of Wisconsin, Milwaukee, Wisconsin, USA. ${ }^{6}$ Department of Pathology, University of Cambridge, Cambridge, United Kingdom.
\end{abstract}

\begin{abstract}
Fetomaternal alloimmune thrombocytopenia (FMAIT) is caused by maternal generation of antibodies specific for paternal platelet antigens and can lead to fetal intracranial hemorrhage. A SNP in the gene encoding integrin $\beta 3$ causes a clinically important maternal-paternal antigenic difference; Leu33 generates the human platelet antigen 1a (HPA-1a), whereas Pro33 generates HPA-1b. As a potential treatment to prevent fetal intracranial hemorrhage in HPA-1a alloimmunized pregnancies, we generated an antibody that blocks the binding of maternal HPA-1a-specific antibodies to fetal HPA-1a1b platelets by combining a high-affinity human HPA-1a-specific scFv (B2) with an IgG1 constant region modified to minimize Fc $\gamma$ receptor-dependent platelet destruction $(\mathrm{G} 1 \Delta \mathrm{nab})$. B2G1 $\Delta$ nab saturated $\mathrm{HPA}-1 \mathrm{a}^{+}$platelets and substantially inhibited binding of clinical HPA-1a-specific sera to HPA-1a ${ }^{+}$platelets. The response of monocytes to B2G1 $\Delta$ nab-sensitized platelets was substantially less than their response to unmodified B2G1, as measured by chemiluminescence. In addition, B2G1 $\triangle$ nab inhibited chemiluminescence induced by B2G1 and HPA-1a-specific sera. In a chimeric mouse model, B2G1 and polyclonal Ig preparations from clinical HPA-1a-specific sera reduced circulating $\mathrm{HPA}-1 \mathrm{a}^{+}$platelets, concomitant with transient thrombocytopenia. As the $\Delta$ nab constant region is uninformative in mice, $F\left(a^{\prime}\right)_{2}$ B2G1 was used as a proof of principle blocking antibody and prevented the in vivo platelet destruction seen with B2G1 and polyclonal HPA-1a-specific antibodies. These results provide rationale for human clinical studies.
\end{abstract}

\section{Introduction}

Fetomaternal alloimmunization to paternal human platelet antigens (HPAs) is the most common cause of severe thrombocytopenia in term neonates (1), with $75 \%$ of cases due to alloantibodies against HPA-1a (2-5). One in 4 babies born to HPA-1a-immunized mothers have fewer than $20 \times 10^{9}$ platelets/ 1 (5-10), which leads to intracranial hemorrhage (ICH) in $10 \%$ to $20 \%$ of all cases with fetomaternal alloimmune thrombocytopenia (FMAIT), from 16 weeks of pregnancy through the postnatal period $(8,11,12)$. There is no consensus on the most effective antenatal therapy for FMAIT (13). Intrauterine transfusions (IUTs) of HPA- $1 \mathrm{a}^{-}$platelets are a logistical challenge (14), and the risk of fetal loss is up to $15 \%(15-18)$. Several trials have shown the benefit of intravenous immunoglobulin (IVIG) therapy, but in 50\% of patients with severe disease (ICH in the previous pregnancy or an initial fetal platelet count of fewer than $\left.20 \times 10^{9} / 1\right)$, IVIG therapy does not achieve a safe fetal

Nonstandard abbreviations used: $\mathrm{CL}$, chemiluminescence; $\mathrm{F} c \gamma \mathrm{R}, \mathrm{Fc} \gamma$ receptor; FMAIT, fetomaternal alloimmune thrombocytopenia; HPA-1a, human platelet antigen $1 \mathrm{a} ; \mathrm{Hu} \beta 3 \mathrm{Pt}$, platelets expressing human $\beta 3$; IBGRL, International Blood Group Reference Laboratory; ICH, intracranial hemorrhage; ID50, 50\% inhibition of binding; IUT, intrauterine transfusion; IVIG, intravenous immunoglobulin; MAIPA, monoclonal antibody immobilization of platelet antigen (assay); UPN, unique patient number. Conflict of interest: K.L. Armour, M.R. Clark, and L.M. Williamson have filed a patent application for the use of the mutant IgG constant region studied here. Citation for this article: J. Clin. Invest. 118:2929-2938 (2008). doi:10.1172/JCI34708 platelet count (19-23). Although IVIG therapy may reduce the incidence of ICH in this high-risk group without a rise in platelet count (24), ICHs still occur in some cases $(21,25,26)$. The most common side effects of IVIG therapy, such as headaches, myalgia, and allergic reactions, can be easily treated (27). However, the infectious risk associated with pooled blood products such as IVIG cannot be dismissed, as a previous outbreak of hepatitis $\mathrm{C}$ associated with plasma-derived anti-D immunoglobulin has shown (28, 29 ), and there is concern over emerging infectious agents such as prions, for which donors are not screened and which are resistant to heat treatment (30). IVIG therapy is expensive and its chronic worldwide shortage well documented $(31,32)$. Therefore, a safe and effective recombinant alternative for antenatal treatment of FMAIT would be useful.

It has been shown that the binding site for polyclonal HPA-1a antibodies is limited to a finite number of epitopes on the $\beta 3$ integrin, with Leu33 being a critical residue in the antibody binding site (33). We reasoned that it should be possible to generate a recombinant nondestructive blocking HPA-1a antibody of sufficiently high affinity to block binding of maternal polyclonal HPA-1a antibodies to fetal HPA- $1 \mathrm{a} 1 \mathrm{~b}$ platelets. A potential therapeutic antibody would require an Fc portion to maintain the long half-life of $\operatorname{IgG}(34)$ and to mediate placental transport via FcRn (35), removing the need for hazardous intrauterine administration. The precise mechanism of platelet destruction is assumed to involve the high-affinity Fc $\gamma$ 


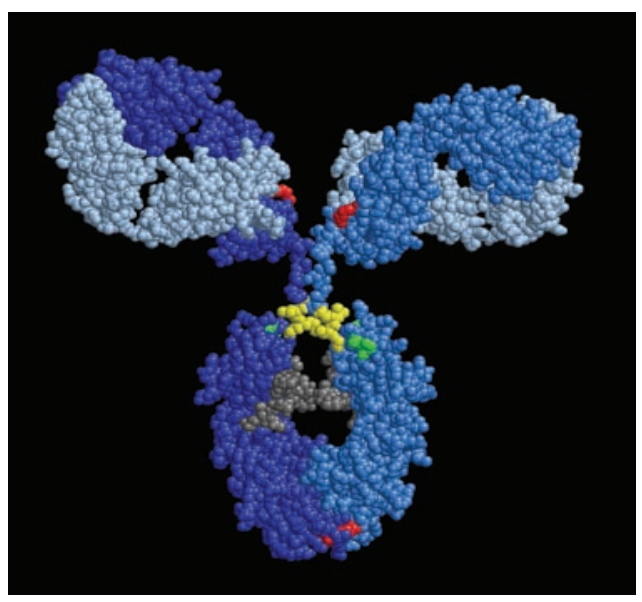

\section{Figure 1}

Model of human IgG1 indicating the positions of the mutated residues in the modified nondestructive G1 $\Delta$ nab constant region. The immunoglobulin IgG heavy chains are shown in light blue and the immunoglobulin light chains and Fc-associated carbohydrate in dark gray. The red residues were altered by the $\Delta \mathrm{n}$ mutation in order to replace the lgG1 G1m $(1,17)$ allotypic residues Lys214, Asp356, and Leu358 with the corresponding IgG2 residues Thr, Glu, and Met. The blue amino acids are IgG1 residues Ala327, Ala330, and Pro331 changed to the IgG4 residues Gly, Ser, and Ser by the $\Delta$ a mutation. The green residues of IgG1 (Glu233, Leu234, Leu235, and Gly236) were substituted with the corresponding amino acids of IgG2 (Pro, Val, Ala, and a deleted residue) by the $\Delta \mathrm{b}$ mutation. The image was generated from the PDB file of an IgG1 model (59) using RasMol V2.7.3.

receptors $\left(\mathrm{F}_{\mathrm{c}} \mathrm{R} \mathrm{Rs}\right)$ on effector cells. The therapeutic antibody $\mathrm{Fc}_{\mathrm{c}}$ portion would therefore have to be modified to prevent binding to Fc $\gamma$ Rs, particularly the high-affinity Fc $\gamma$ RI (CD64).

We previously generated a human single-chain variable domain antibody fragment $(\mathrm{scFv})$ of nanomolar affinity $\left(K_{\mathrm{d}}=6 \times 10^{-8} \mathrm{M}\right)$ for HPA-1a from the maternal B cells of a case of FMAIT by phage display $(36,37)$. The recombinant $\operatorname{IgG1}$ antibody (B2G1) derived from this $\mathrm{scFv}$ was sufficiently specific for HPA-1a to permit its use as a routine phenotyping reagent (38).

To generate a complete antibody lacking destructive activity, residues from IgG2 and IgG4 were substituted into regions of the IgG1 CH2 domain involved in binding to Fc $\gamma \mathrm{RI}-\mathrm{Fc} \gamma \mathrm{RIII}$ and complement C1q. Residues of IgG1 responsible for the immunogenic $\mathrm{Gm}$ allotype were replaced by the non-immunogenic residues from IgG2 (Figure 1) (39). Platelets sensitized with the wild-type IgG1 anti-HPA-1a described above have been shown to trigger monocyte chemiluminescence (CL) in an interaction mediated by Fc $\gamma \mathrm{RI}$ and Fc $\gamma$ RII (40). It is therefore logical to hypothesize that the modified recombinant HPA-1a antibody $(\mathrm{B} 2 \mathrm{G} 1 \Delta \mathrm{nab})$ could block binding of maternal HPA-1a antibodies to platelets, reduce monocyte activation, and ultimately prevent platelet destruction.

The biallelic HPA-1 system only exists in humans, and there is no satisfactory animal model to investigate the possible use of these recombinant antibodies. Ni and colleagues developed a murine model to look at the efficacy of IVIG therapy, but their study relied on isotypic antibodies generated in $\beta 3$-deficient ( $\beta 3^{-/-}$mice) against a $\beta 3^{+/-}$fetus (41). We therefore generated $\beta 3^{-/-}$mice transplanted with littermate bone marrow transduced with a lentivirus vector containing the human $\beta 3$ gene ITGB3 encoding either
Leu33 (HPA-1a) or Pro33 (HPA-1b). Transplanted mice express a hybrid murine/human $\alpha \mathrm{IIb} \beta 3$ complex on the platelet surface as previously described (42) but crucially, this complex bears the corresponding HPA-1a or $-1 \mathrm{~b}$ antigen, making the mice suitable for use in studying the effects of natural and recombinant human HPA-1a antibodies on platelet survival in vivo.

This study demonstrates that the modified HPA-1a antibody B2G1 1 nab inhibits binding of maternal HPA-1a antibodies from FMAIT cases to platelets and abrogates monocyte CL responses to anti-HPA-1a-coated platelets and that its $\mathrm{F}\left(\mathrm{ab}^{\prime}\right)_{2}$ fragment prevents removal from murine circulation of HPA-1a-expressing platelets by destructive HPA-1a antibodies.

\section{Results}

Binding of IgG1 and mutated recombinant HPA-1 a antibodies to HPA-1a1b platelets. We assessed the binding characteristics of the parent IgG1 (B2G1) and modified antibody (B2G1 $\Delta$ nab) to the HPA-1a antigen on the surface of HPA-1a1b platelets (matching the fetal phenotype). In flow cytometry and the monoclonal antibody immobilization of platelet antigen (MAIPA) assay, dilutions of B2G1 and B2G1 1 nab demonstrated identical levels of binding to HPA-1a1b platelets, with saturation at $5 \mu \mathrm{g} / \mathrm{ml}$ (data not shown). There was no binding to homozygous HPA-1b1b platelets (data not shown).

Competition studies were carried out in the MAIPA using $\mathrm{F}\left(\mathrm{ab}^{\prime}\right)_{2}$ B2G1 as a blocking antibody. Binding of $10 \mu \mathrm{g} / \mathrm{ml} \mathrm{B} 2 \mathrm{G} 1$ and B2G1 1 nab to platelets was inhibited to the same extent by $F\left(a b^{\prime}\right)_{2}$ $\mathrm{B} 2 \mathrm{G} 1$, requiring 3, 8, and $50 \mu \mathrm{g} / \mathrm{ml}$ to achieve $50 \%, 70 \%$, and maximum (98\%) inhibition (data not shown).

Monocyte CL responses to IgG1 and mutated recombinant $H P A-1$ a antibodies. We assessed the effect on monocyte activation of the mutations introduced in the constant region of the modified antibody $\mathrm{B} 2 \mathrm{G} 1 \Delta \mathrm{nab}$. The monocyte CL response to HPA-1a1b platelets sensitized with the parent IgG1 B2G1 reached a maximum at $10 \mu \mathrm{g} / \mathrm{ml}$ (Figure 2, A and B). The CL responses to B2G1 $\Delta$ nab-sensitized HPA-1a1b platelets were reduced to less than $15 \%$ of $B 2 \mathrm{G} 1$ values $(P<0.001)$ across the antibody concentration range (Figure 2, A and $\mathrm{B}$ ) but were above that observed with the control antibody VAZO-5 or F( $\left(\mathrm{ab}^{\prime}\right)_{2}$ B2G1 (Figure 2, A and B). No CL response was obtained with HPA-1b1b platelets (data not shown).

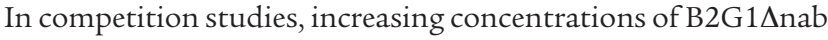
inhibited the CL response to $10 \mu \mathrm{g} / \mathrm{ml} \mathrm{B} 2 \mathrm{G} 1$ (Figure 2C), requiring 26,49 , and more than $500 \mu \mathrm{g} / \mathrm{ml}$ to achieve $50 \%, 70 \%$, and maximum (85\%) inhibition, respectively (Figure 2D).

Inbibition of platelet binding and CL responses to maternal polyclonal anti-HPA-1a by recombinant HPA-1a antibodies. Assays were performed to determine whether $\mathrm{F}\left(\mathrm{ab}^{\prime}\right)_{2} \mathrm{~B} 2 \mathrm{G} 1$ could inhibit binding of maternal polyclonal HPA-1a antibodies from 20 FMAIT cases and whether $\mathrm{B} 2 \mathrm{G} 1 \Delta \mathrm{nab}$ could reduce monocyte responses to the same sera. The anti-HPA-1a potencies of the maternal sample ranged from 0.01 to $193 \mathrm{IU} / \mathrm{ml}$, and the monocyte CL signal induced by each sample ranged from 0.3 to 31.2 CL units (Table 1). Each patient was assigned a unique patient number (UPN).

For all maternal sera, we established inhibition curves in the MAIPA assay using $\mathrm{F}\left(\mathrm{ab}^{\prime}\right)_{2}$ B2G1 as described above, and the concentrations were calculated for $\mathrm{F}\left(\mathrm{ab}^{\prime}\right)_{2} \mathrm{~B} 2 \mathrm{G} 1$, which was found to inhibit binding by 50\% (50\% inhibition of binding [ID50]), 70\% (ID70), and by the maximum amount achievable.

For 18 sera, the ID50 values ranged from 4.8 to $616 \mu \mathrm{g} / \mathrm{ml} \mathrm{F}\left(\mathrm{ab}^{\prime}\right)_{2}$

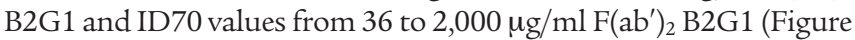
$3 \mathrm{~A})$. The maximum achievable inhibition of binding ranged from 
A
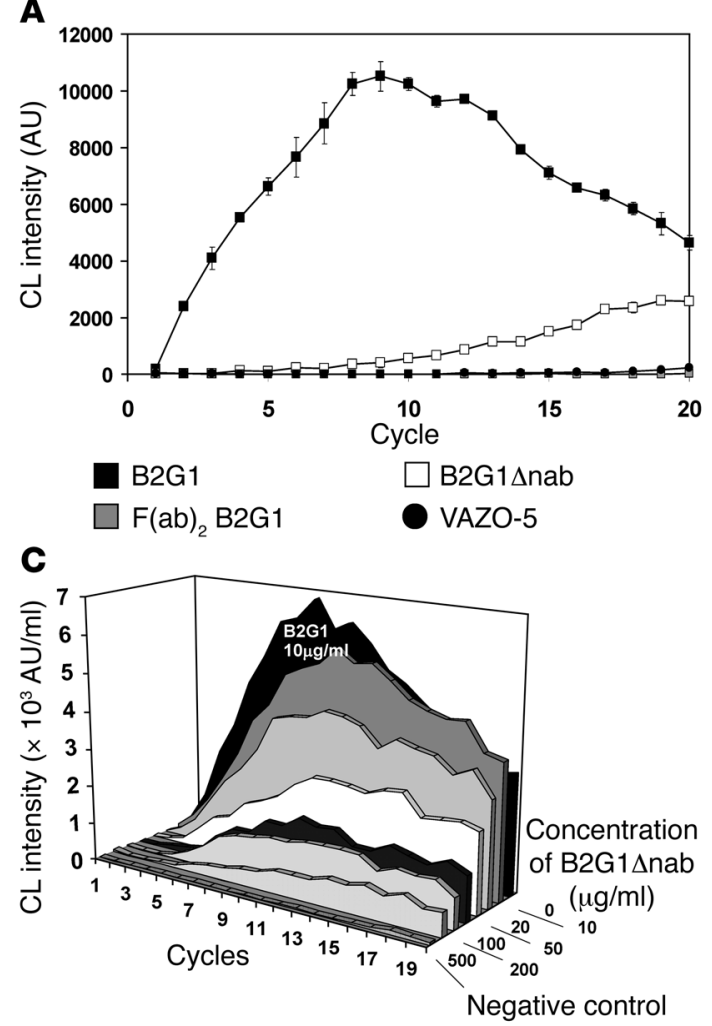

B

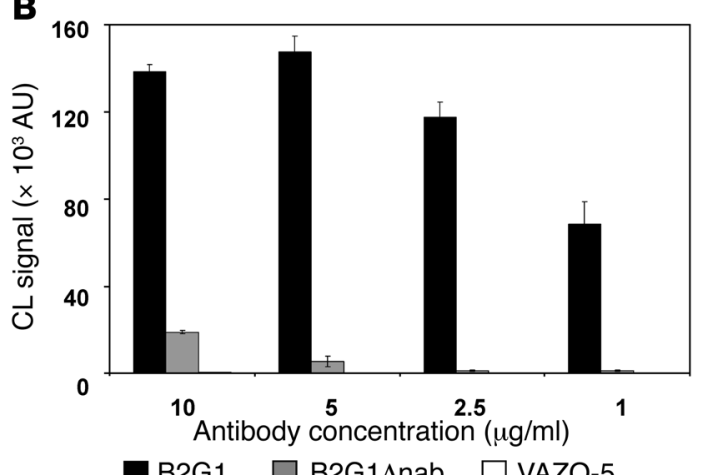

B2G1

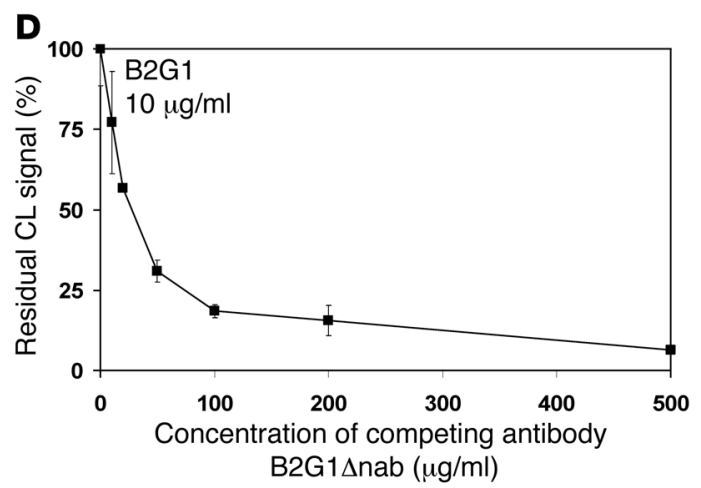

Figure 2

Monocyte CL response to recombinant HPA-1a antibodies. (A) CL response to HPA-1a1b platelets sensitized with $10 \mu \mathrm{g} / \mathrm{ml}$ of B2G1, B2G1 $\Delta$ nab, $\mathrm{F}\left(\mathrm{ab}^{\prime}\right)_{2}$ B2G1, and a negative control antibody VAZO-5. CL intensity was recorded over 20 cycles of 2.35 minutes each. (B) The CL signal corresponding to the sum of the $C L$ intensity for the 20 cycles (surface under the curve) recorded with decreasing concentrations of B2G1, B2G1 $\triangle$ nab, and VAZO-5. (C) Competition study in the CL assay. HPA-1a1b platelets were sensitized with $10 \mu \mathrm{g} / \mathrm{ml} \mathrm{B2G1}$ and decreasing concentrations of B2G1 $\Delta$ nab. (D) Competition curve generated from the results in C. The CL signal obtained with $10 \mu \mathrm{g} / \mathrm{ml} \mathrm{B2G1} \mathrm{in} \mathrm{the} \mathrm{absence} \mathrm{of} \mathrm{the} \mathrm{competing}$ antibody B2G1 $\Delta$ nab corresponds to $100 \%$ residual CL signal on the graph. Data are the mean \pm SD of 3 separate experiments.

$70 \%$ to $97 \%$ (Figure $3 \mathrm{~A}$ ), with a $\mathrm{F}\left(\mathrm{ab}^{\prime}\right)_{2} \mathrm{~B} 2 \mathrm{G} 1$ concentration ranging from 20 to $4,000 \mu \mathrm{g} / \mathrm{ml}$ (Figure 3A). In one case the maternal HPA1a antibody was too weak to establish an inhibition curve, and in another the $\mathrm{F}\left(\mathrm{ab}^{\prime}\right)_{2} \mathrm{~B} 2 \mathrm{G} 1$ increased the OD by 3 -fold. This particular serum was found by ELISA to contain anti-F $\left(\mathrm{ab}^{\prime}\right)_{2}$ antibodies (data not shown). In a further experiment, $\mathrm{F}\left(\mathrm{ab}^{\prime}\right)_{2} \mathrm{~B} 2 \mathrm{G} 1$ was added 20 minutes after pre-sensitization of the platelets with each of 5 maternal sera, at a concentration previously shown to inhibit binding by $50 \%$. The degree of inhibition was comparable with that obtained when both were added concomitantly (Figure 4). This result proves the ability of the recombinant antibodies to displace maternal polyclonal antibodies already bound to platelets. There was, however, no correlation between maternal antibody potency and concentrations of mutant antibody required for inhibition of binding (Table 1).

Inhibition curves were generated in the CL assay for all clinical samples using increasing concentrations of B2G1 $1 \Delta$ nab mixed with a fixed amount of polyclonal serum. The concentrations of $\mathrm{B} 2 \mathrm{G} 1 \Delta \mathrm{nab}$ that inhibited the $\mathrm{CL}$ response to each polyclonal serum by $50 \%, 70 \%$, and the maximum amount achievable were calculated. In 17 cases, the ID50 values ranged from 6 to $560 \mu \mathrm{g} / \mathrm{ml}$ $\mathrm{B} 2 \mathrm{G} 1 \Delta \mathrm{nab}$ and the ID70 values from 10 to $1,940 \mu \mathrm{g} / \mathrm{ml}$ B2G1 $1 \Delta \mathrm{nab}$ (Figure $3 \mathrm{~B}$ ). The maximum inhibition achieved in the CL assay ranged from $72 \%$ to $95 \%$ for the 15 pure anti-HPA-1a sera (Figure

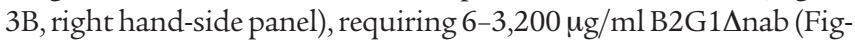

ure $3 \mathrm{~B})$. For 2 sera known to contain a mixture of HPA-1a and $-5 b$ antibodies, maximum inhibition was $55 \%$ and $65 \%$, respectively (the platelets used in the assay were from a HPA-5a5b heterozygous donor). In 3 cases the CL signal was too weak to establish an inhibition curve. There was no correlation between concentrations of inhibitory antibody required in the CL studies and maternal antibody potency, nor between concentrations required for the same degree of inhibition in MAIPA and CL.

A murine model to study inbibition of HPA-1 a platelet destruction by blocking antibodies in vivo. Bone marrow from $\beta 3^{-/-}$mice was transduced with a viral construct containing the human ITGB3 cDNA encoding either leucine or proline at position 33 (HPA-1a or -1b, respectively), and the transduced bone marrow was transplanted into lethally irradiated $\beta 3^{-/-}$mice. Upon bone marrow recovery, the transplanted mice had a chimeric platelet population, containing platelets generated from the original $\beta 3^{-/-}$megakaryocytes and platelets expressing the human $\beta 3$ (Huß3 Pt) and the corresponding HPA-1a or -1b epitope (Figure 5). Huß3 Pt chimerism levels (the fraction of $\mathrm{Hu} \beta 3 \mathrm{Pt}$ present in circulation expressed as a percentage of the total platelet population) varied from $10 \%$ to $60 \%$ in the HPA-1a mice $(n=10)$ and from $54 \%$ to $81 \%$ in the HPA- $1 \mathrm{~b}$ mice $(n=4)$. Specific binding of FITC-B2G1 confirmed the expression of the HPA-1a antigen on platelets circulating within HPA-1a mice. HPA-1a was not detected on the platelets of HPA- $1 \mathrm{~b}$ or $\beta 3^{-/-}$mice (Figure 5 ). 


\section{Table 1}

Clinical details, HPA-1a antibody potency, CL signal, and inhibition data

\begin{tabular}{|c|c|c|c|c|c|c|c|c|}
\hline UPN & $\begin{array}{l}\text { Platelet count } \\
\text { at birth }\left(\times 10^{9} / 1\right)\end{array}$ & $\mathrm{ICH}$ & $\begin{array}{l}\text { Potency } \\
\text { (AU/ml) }\end{array}$ & $\begin{array}{l}\text { CL signal } \\
(\mathrm{AU} / \mathrm{ml})\end{array}$ & $\begin{array}{l}\text { Maximum } \\
\text { inhibition in } \\
\text { MAIPA, \% } \\
\text { (dilution factor) }\end{array}$ & $\begin{array}{c}\text { Conc. of } \\
\mathrm{F}\left(\mathrm{ab}^{\prime}\right)_{2} \text { B2G1 at } \\
\text { maximum MAIPA } \\
\text { inhibition }(\mu \mathrm{g} / \mathrm{ml})\end{array}$ & $\begin{array}{l}\text { Maximum } \\
\text { inhibition } \\
\text { in CL (\%) }\end{array}$ & $\begin{array}{c}\text { Conc. of } \\
\text { B2G1 } \Delta \text { nab at } \\
\text { maximum CL } \\
\text { inhibition }(\mu \mathrm{g} / \mathrm{ml})\end{array}$ \\
\hline 1 & 262 & No & $<0.5$ & 2 & $N D^{A}$ & $N D^{A}$ & $N D^{B}$ & $N D^{B}$ \\
\hline 2 & 2 & Yes & 1.7 & 5 & $N D^{C}$ & $N D^{C}$ & 72 & 6 \\
\hline 3 & 3 & Yes & 1.7 & 16 & $97(1 / 2)$ & 800 & 91 & 400 \\
\hline 4 & 12 & Yes & 7.1 & 18 & $72(1 / 4)$ & 36 & 88 & 400 \\
\hline 5 & 19 & No & 7.5 & 17 & $80(1 / 4)$ & 800 & 87 & 3,200 \\
\hline 6 & 5 & No & 13 & 24 & $95(1 / 8)$ & 800 & 91 & 80 \\
\hline 7 & $211^{D}$ & No & 14 & 11 & $80(1 / 8)$ & 800 & 82 & 3,200 \\
\hline $8 \mathrm{E}$ & 19 & No & 15 & 19 & $86(1 / 8)$ & 4,000 & 55 & 400 \\
\hline $9^{E}$ & 5 & No & 23 & 10 & $89(1 / 8)$ & 4,000 & 65 & 40 \\
\hline 10 & 101 & No & 31 & 0.3 & $70(1 / 8)$ & 2,000 & $N D^{B}$ & $N D^{B}$ \\
\hline 11 & 84 & No & 31 & 22 & $82(1 / 8)$ & 800 & 87 & 3,200 \\
\hline 12 & 6 & Yes & 33 & 24 & $78(1 / 8)$ & 4,000 & 87 & 3,200 \\
\hline 13 & 7 & No & 33 & 19 & $70(1 / 8)$ & 2,000 & 75 & 3,200 \\
\hline 14 & 8 & Yes & 98 & 30 & $77(1 / 8)$ & 2,000 & 80 & 3,200 \\
\hline 15 & 2 & No & 99 & 26 & $87(1 / 8)$ & 2,000 & 93 & 3,200 \\
\hline 16 & 17 & Yes & 100 & 23 & $95(1 / 8)$ & 4,000 & 87 & 3,200 \\
\hline 17 & 8 & No & 193 & 32 & $86(1 / 8)$ & 200 & 92 & 3,200 \\
\hline 18 & 32 & No & $N D^{F}$ & 28 & $85(1 / 8)$ & 2,000 & 94 & 3,200 \\
\hline 19 & 234 & No & $N D^{F}$ & 4 & $82(1 / 4)$ & 800 & $N D^{B}$ & $N D^{B}$ \\
\hline 20 & 10 & Yes & $N D^{F}$ & 6 & $97(1 / 4)$ & 2,000 & 80 & 80 \\
\hline
\end{tabular}

APotency too weak for competition studies. ${ }^{B} \mathrm{CL}$ signal too weak for competition studies. 'Binding to HPA-1a1b platelets increased in the presence of $\mathrm{F}(\mathrm{ab})_{2}$ B2G1 by 3-fold. DIUTs. ESera containing both HPA-1a and HPA-5b antibodies. FNon-parallel lines with the proposed anti-HPA-1a standard due to the presence of anti- $\mathrm{F}\left(\mathrm{ab}^{\prime}\right)_{2}$ antibodies in the patient's serum. Conc., concentration; ND, not determined.

We first assessed the in vivo destructive effect of the recombinant IgG1 HPA-1a antibody B2G1 on the Huß3 Pt by i.p. injection. To be able to compare the different animals entered into the experiment, the remaining fraction of $\mathrm{Hu} \beta 3 \mathrm{Pt}$ present in circulation after i.p. injection was expressed as a percentage of the baseline $\mathrm{Hu} \beta 3 \mathrm{Pt}$ chimerism for each mouse. In calculating the amount of antibody necessary to achieve thrombocytopenia, we assumed complete absorption from the i.p. injection into a 2 - $\mathrm{ml}$ circulatory blood volume. i.p. injection of $25 \mu \mathrm{g}$ B2G1 (i.e., $\sim 12.5 \mu \mathrm{g} / \mathrm{ml}$ in circulation) in $3 \mathrm{HPA}-1$ a mice (baseline $\mathrm{Hu} \beta 3 \mathrm{Pt}$ chimerisms of $49 \%, 21 \%$, and $12 \%$ ) resulted in a drop in $\mathrm{Hu} \beta 3$ Pt levels of $18 \%-67 \%$ at 1 hour, reaching maximum reduction of $67 \%-93 \%$ at 4 hours (Figure $6 \mathrm{~A}$ ). In the 2 highest expressors, this was reflected by a decrease in platelet count proportional to their baseline Huß3 Pt chimerism (Figure 6B). There was no effect of B2G1 on Huß3 Pt or platelet count in HPA-1b (Figure 6, A and B) or in $\beta 3^{-/-}$mice (Figure $6 \mathrm{~B}$ ). Hu $\beta 3$ Pt levels returned to baseline in all HPA-1a mice 7-10 days after the experiment.

Since the mouse $\mathrm{F} c \gamma \mathrm{R}$ profile is different from that in humans (43), using the B2G1 1 nab construct whose constant region has been tailored to abrogate binding to human $\mathrm{Fc} \gamma \mathrm{R}$ would be uninformative. Therefore, we opted to use a $\mathrm{F}\left(\mathrm{ab}^{\prime}\right)_{2}$ construct of B2G1 that lacks a constant region altogether and therefore does not bind to either human or mouse $\mathrm{Fc} \gamma \mathrm{R}$ as a proof of principle protective antibody. To assess the ability of $\mathrm{a} \mathrm{F}\left(\mathrm{ab}^{\prime}\right)_{2}$ fragment of B2G1 to inhibit B2G1-induced platelet clearance, competition studies were performed in 3 HPA-1a mice (Huß3 Pt chimerism of $53 \%, 21 \%$, and $10 \%$ ). Platelet destruction studies were first performed as described above using $25 \mu \mathrm{g}$ B2G1 i.p. injection, and the clearance of $\mathrm{Hu} \beta 3 \mathrm{Pt}$ was confirmed (Figure 6C, solid lines). After the peripheral platelet counts returned to normal, the mice were entered into the competition study. Given the shorter half-life of a $\mathrm{F}\left(\mathrm{ab}^{\prime}\right)_{2}$ fragment compared with a full-length antibody in vivo, the mice had a loading dose of $150 \mu \mathrm{g} \mathrm{F}\left(\mathrm{ab}^{\prime}\right)_{2}$ B2G1 i.p. 1 hour prior to injecting $25 \mu \mathrm{g} \mathrm{B} 2 \mathrm{G} 1$ i.p., followed by $150 \mu \mathrm{g} \mathrm{F}\left(\mathrm{ab}^{\prime}\right)_{2} \mathrm{~B} 2 \mathrm{G} 1$ i.p. at 0,1 , and 3 hours (Figure $6 \mathrm{C}$ ). In all 3 mice, the proportion of $\mathrm{Hu} \beta 3 \mathrm{Pt}$ remaining in circulation after injection of $\mathrm{B} 2 \mathrm{G} 1$ in the presence of $\mathrm{F}\left(\mathrm{ab}^{\prime}\right)_{2} \mathrm{~B} 2 \mathrm{G} 1$ was close to baseline values, supporting its protective effect (Figure 6C, dotted lines).

To carry out equivalent in vivo studies using polyclonal FMAIT sera, we generated 2 polyclonal IgG preparations (CAM00D and CAM00E) from 2 FMAIT cases. CAM00D and CAM00E anti-HPA-1a potency was measured by MAIPA as 2,500 and $70 \mathrm{IU} / \mathrm{ml}$, respectively (high concentrations were deliberately generated to take into account the dilution in the mice's circulatory volumes). Competition studies of binding were carried out using MAIPA with $F\left(a b^{\prime}\right)_{2}$ B2G1 as described above, using dilutions of 1/200 (12.5 IU/ml) and $1 / 40(1.75 \mathrm{IU} / \mathrm{ml})$ for CAM00D and CAM00E, respectively. Results corrected for the dilution factor are shown in Figure 7A. ID50 and ID70 were reached at 5 and $20 \mathrm{mg} \mathrm{F}\left(\mathrm{ab}^{\prime}\right)_{2}$ B2G1, respectively, for CAM00D and at 0.4 and $2.4 \mathrm{mg} \mathrm{F}\left(\mathrm{ab}^{\prime}\right)_{2} \mathrm{~B} 2 \mathrm{G} 1$, respectively, for CAM00E. Maximum inhibition was $82 \%$ for CAM00D with $200 \mathrm{mg} \mathrm{F}\left(\mathrm{ab}^{\prime}\right)_{2}$ B2G1 and 83\% for CAM00E with $20 \mathrm{mg} \mathrm{F}\left(\mathrm{ab}^{\prime}\right)_{2}$ $\mathrm{B} 2 \mathrm{G} 1$. These high values reflect the high concentration of HPA-1a antibodies in these 2 preparations.

Two mice (Huß3 Pt chimerism of $49 \%$ and $60 \%$, respectively) were injected i.p. with $100 \mu \mathrm{l}$ CAM00D (i.e., $~ 125 \mathrm{IU} / \mathrm{ml}$ in circulation) and 1 mouse (Huß3 Pt chimerism of 34\%) with $10 \mu \mathrm{l}$ (i.e. $~ 12.5 \mathrm{IU} / \mathrm{ml}$ in circulation). In all 3 cases, significant platelet destruction was observed, with $\mathrm{Hu} \beta 3 \mathrm{Pt}$ falling to $9 \%-17 \%$ of 

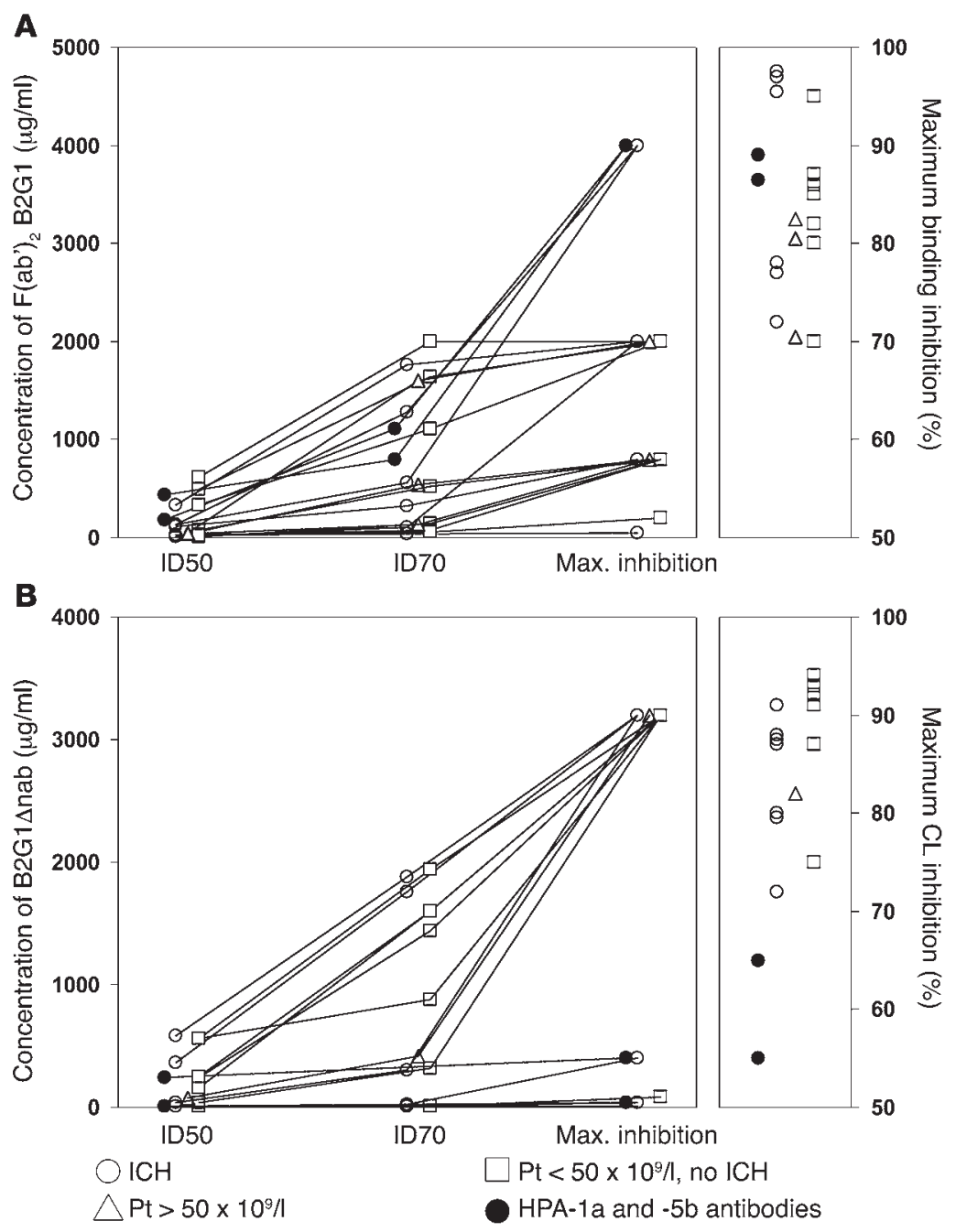

\section{Figure 3}

Competition studies with 20 clinical sera containing HPA-1a antibodies. (A) Concentrations of $F\left(a b^{\prime}\right)_{2}$ B2G1 $(\mu \mathrm{g} / \mathrm{ml})$ necessary to inhibit binding in the MAIPA assay by $50 \%$ and $70 \%$ and to achieve maximum inhibition for each clinical sample. The maximum inhibition achieved (\%) is shown in the right panel. In UPN 1, the maternal HPA-1a antibody was too weak to establish an inhibition curve, and in UPN 2 the $F\left(a b^{\prime}\right)_{2}$ B2G1 increased platelet binding of maternal HPA-1a antibodies by 3-fold. This particular serum was found by ELISA to contain anti-F(ab') antibodies. (B) Concentrations of B2G1 $\Delta \mathrm{nab}(\mu \mathrm{g} / \mathrm{ml})$ necessary to inhibit CL response by $50 \%$ and $70 \%$ and to achieve maximum inhibition for each clinical sample. The maximum inhibition achieved (\%) is shown in the right panel. In 3 cases (UPNs 1, 10, and 19), the CL signal was too weak to establish an inhibition curve. For the 2 samples containing HPA-5b as well as -1 a antibodies (UPNs 8 and 9), maximum inhibition failed to reach $70 \%$. baseline after 4 hours (Figure 7B). No effect was seen in HPA-1b or $\beta 3^{-/-}$mice (data not shown). Competition studies were carried out in 3 mice with Huß3 Pt chimerism equivalent to that of the mice used in the destructive studies (Hu 33 Pt chimerism of $67 \%$, $83 \%$, and $22 \%$, respectively). The first 2 received $100 \mu \mathrm{l}$ CAM00D and $\mathrm{F}\left(\mathrm{ab}^{\prime}\right)_{2} \mathrm{~B} 2 \mathrm{G} 1$ boluses of $260,130,130$, and $130 \mu \mathrm{g}$ at $-1,0$, 1 , and 3 hours, and the last mouse received $10 \mu \mathrm{l}$ CAM00D and $\mathrm{F}\left(\mathrm{ab}^{\prime}\right)_{2} \mathrm{~B} 2 \mathrm{G} 1$ boluses of $50,25,12.5$, and $12.5 \mu \mathrm{g}$ at the same times. In all 3 cases, platelet destruction was prevented by the competing antibody (Figure 7B).

Two mice (Huß3 Pt chimerism of $26 \%$ and $21 \%$ ) were injected i.p. with $200 \mu$ l CAM00E ( 7 IU/ml in circulation). In both mice, platelet destruction was observed, with $\mathrm{Hu} \beta 3 \mathrm{Pt}$ falling to $45 \%-55 \%$ of baseline after 4 hours (Figure 7C). No effect was seen in HPA-1b or $\beta 3^{-/-}$mice (data not shown). Competition studies were carried out in the same mice with $\mathrm{F}\left(\mathrm{ab}^{\prime}\right)_{2} \mathrm{~B} 2 \mathrm{G} 1$ boluses of $100,50,25$, and $25 \mu \mathrm{g}$ given at $-1,0,1$, and 3 hours. In both mice, platelet destruction was completely prevented by the competing antibody (Figure 7C).

\section{Discussion}

The studies reported here confirm that it is possible to inhibit the binding of human polyclonal HPA-1a antibodies to HPA-1a1b platelets with a single human recombinant HPA-1a antibody
(B2G1), and that the addition of a modified constant region (B2G1 $\mathrm{nab}$ ) abrogates monocyte CL responses to anti-HPA-1a sensitized platelets. Furthermore, we show in a unique murine model that HPA-1a antibody-induced platelet clearance is prevented in vivo by $\mathrm{F}\left(\mathrm{ab}^{\prime}\right)_{2} \mathrm{~B} 2 \mathrm{G} 1$.

In competition studies, $70 \%-95 \%$ inhibition of anti-HPA- $1 \mathrm{a}$ binding to platelets was seen with all but one clinical sera tested. Anti- $\left.\mathrm{F}(\mathrm{ab})_{2}\right)_{2}$ antibodies were later found in this sample (data not shown), which may explain this discrepant result. The concentration of $\mathrm{F}\left(\mathrm{ab}^{\prime}\right)_{2} \mathrm{~B} 2 \mathrm{G} 1$ necessary to inhibit platelet binding was variable but showed no correlation with maternal anti-HPA-1a potency. This may be because the potency of each polyclonal serum depends on both the concentration and affinity of each of its constituent antibody clones with variation in on/off rates for antigen binding. There were sera for which complete inhibition of binding could be achieved at low concentrations of inhibitor antibody $(800 \mu \mathrm{g} / \mathrm{ml})$ (UPNs 3 and 6), and in contrast, there were also sera that showed more than $20 \%$ residual binding (UPNs 4, 10, 12, 13, and 14), even with $4,000 \mu \mathrm{g} / \mathrm{ml}$ of $\mathrm{F}\left(\mathrm{ab}^{\prime}\right)_{2} \mathrm{~B} 2 \mathrm{G} 1$ (Table 1). This cannot be explained by major differences in affinity between B2G1 $\left(K_{\mathrm{d}}=6 \times 10^{-8} \mathrm{M}\right)(37)$ and the polyclonal sera, as there is good evidence that even highaffinity polyclonal antibodies have at most a $K_{\mathrm{d}}$ of $0.3 \times 10^{-9}$ to $1 \times 10^{-9} \mathrm{M}$ (44). HPA-1a polyclonal sera have different footprints on 


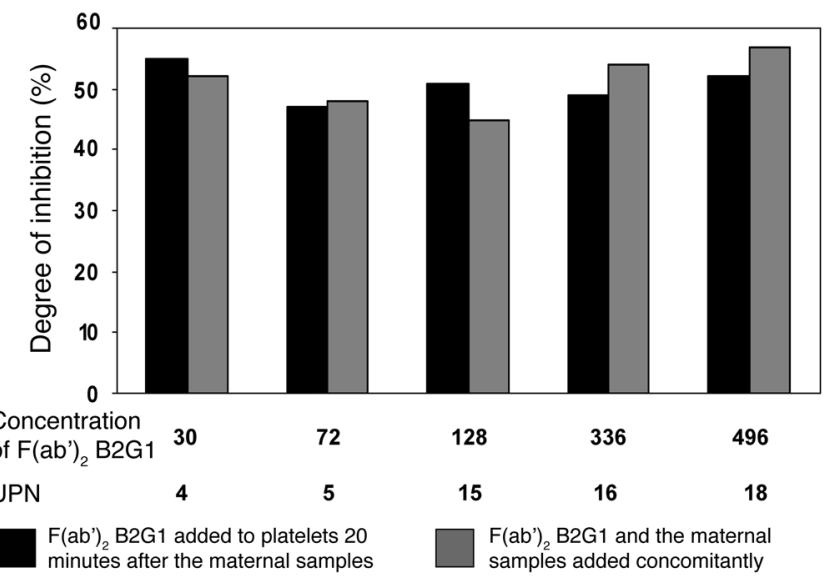

the $\beta 3$ integrin $(45,46)$ : type I antibodies, which bind to the plexin semaphorin integrin (PSI) domain (e.g., the first 54 residues of $\beta 3$ ), and type II antibodies, which require residues outside the PSI domain. The competition results may therefore also reflect the differences between the antibody footprints covered by the maternal polyclonal antibodies and that covered by our monoclonal antibody (which belongs to the type II category).

Monocyte CL responses to platelets sensitized with the modified HPA-1a antibody were reduced by $85 \%$ when compared with the IgG1 parent antibody. These results are in keeping with the previous observation that the $\Delta$ nab mutations reduced the binding of a human RhD IgG1 $\Delta$ nab antibody to Fc $\gamma$ RI by $10^{4}$-fold (39) and to the stimulatory receptor Fc $\gamma$ RIIa by 10 -fold (47). The mutated RhD antibodies, when coated onto RhD-positive red cells, also failed to stimulate monocyte CL responses (39), a parameter previously shown to correlate with the severity of hemolytic disease of the newborn (48). However, in contrast to the complete absence of monocyte CL responses observed in the red cell studies, B2G1 $\Delta$ nab elicited a residual response in excess of that seen with a $\mathrm{F}\left(\mathrm{ab}^{\prime}\right)_{2}$ anti-HPA-1a antibody that lacks a constant region altogether. This difference may be an in vitro artefact explained by P-selectin-mediated direct adhesion of platelets to monocytes, which enhances both the rate and, at low antibody concentrations, the magnitude of the monocyte CL response to anti-HPA-1a-sensitized platelets (40).

In keeping with the effect on platelet binding, we have shown that monocyte CL responses induced by heterozygous platelets sensitized with maternal HPA-1a antibodies could be inhibited by more than $70 \%$ in all cases in which anti-HPA-1a was present alone. For the 2 sera that also contained anti-HPA-5b, maximum inhibition

\section{Figure 5}

Platelet chimerism in $\beta 3^{-/-}$transplanted mice and specific expression of the HPA-1a epitope. Lethally irradiated $\beta 3^{--}$mice were transplanted with bone marrow from $\beta 3^{--}$mice transduced with a viral construct containing the human ITGB3 cDNA encoding either leucine or proline at position 33 (HPA-1a or -1b, respectively). Upon bone marrow recovery, the transplanted mice had a chimeric platelet population, containing platelets generated from the original $\beta 3^{-/-}$megakaryocytes and Huß3 Pt as shown in the top panel, where platelets were stained with the PE-labeled human $\beta 3$-specific antibody VI-PL2. The bottom panel shows specific binding of the FITC-labeled HPA-1a recombinant antibody B2G1 to platelets in mice transplanted with bone marrow transduced with the Leu33 human $\beta 3$.

\section{Figure 4}

Competition studies with 5 clinical sera containing HPA-1a antibodies with concomitant and postponed addition of $F\left(a b^{\prime}\right)_{2}$ B2G1. To assess the ability of the recombinant antibodies to displace polyclonal antibodies already bound to platelets, $F\left(a b^{\prime}\right)_{2} B 2 G 1$ was added 20 minutes after pre-sensitization of the platelets with each of 5 maternal sera, at a concentration previously shown to inhibit binding by $50 \%$ and inhibition compared with that obtained when both were added concomitantly.

was notably less (55\% and 65\%), as the platelets used in the experiment were from a heterozygous HPA-5a5b donor. Since the epitopes defining the HPA-5 antigens are on platelet glycoprotein Ia ( $\alpha 2$ integrin), these findings are consistent with the inhibitory effect of the B2 mutated monoclonal antibodies being blockade of the interaction between maternal anti-HPA-1a and its epitope.

The murine studies confirmed the effectiveness of using a blocking HPA-1a antibody with reduced binding to $F c \gamma$ R to prevent platelet destruction. The B2G1 $\Delta$ nab construct in mice competition studies would have been uninformative because human IgG2 and IgG4 antibodies from which the mutations were derived would interact efficiently with murine $\mathrm{Fc} \gamma \mathrm{R}(43,49)$. Instead, as proof of principle, we opted to use a $\mathrm{F}\left(\mathrm{ab}^{\prime}\right)_{2}$ construct that lacks an $\mathrm{Fc}$ domain altogether and therefore does not bind to either human or mouse FcRs. Having demonstrated that the recombinant antibody B2G1 and 2 anti-HPA-1a polyclonal IgG preparations caused clearance only of platelets that expressed the HPA-1a alloantigen, we were able to show that administration of the protective competing antibody $\mathrm{F}\left(\mathrm{ab}^{\prime}\right)_{2} \mathrm{~B} 2 \mathrm{G} 1$ prevented platelet destruction in all 8 mice studied. Interestingly, the dose of $F\left(a b^{\prime}\right)_{2}$

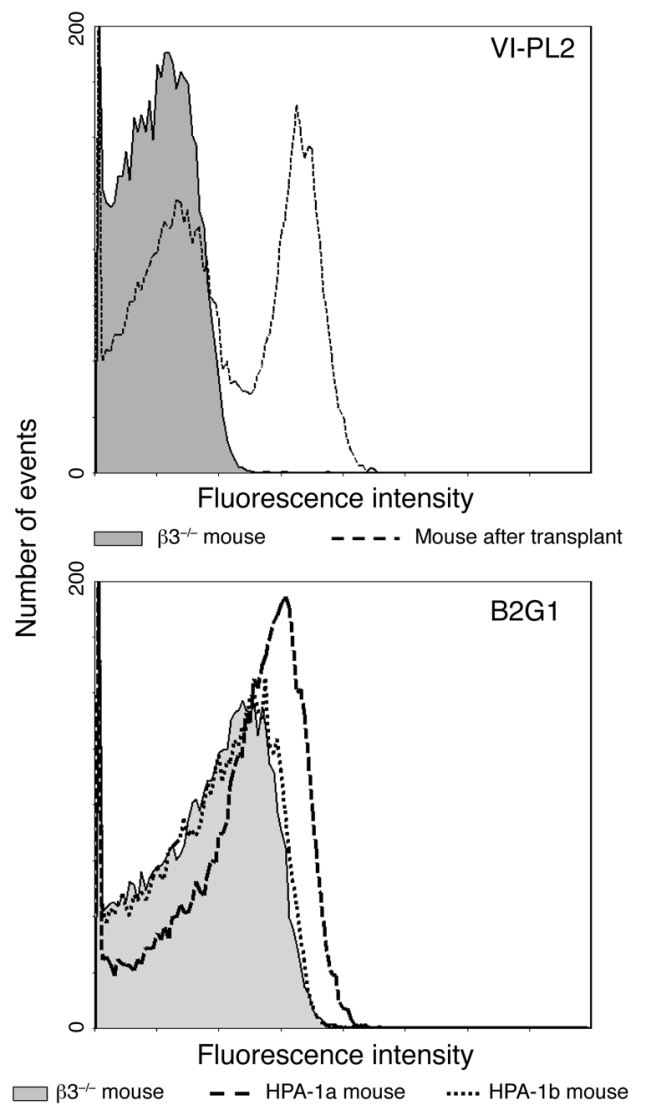


A

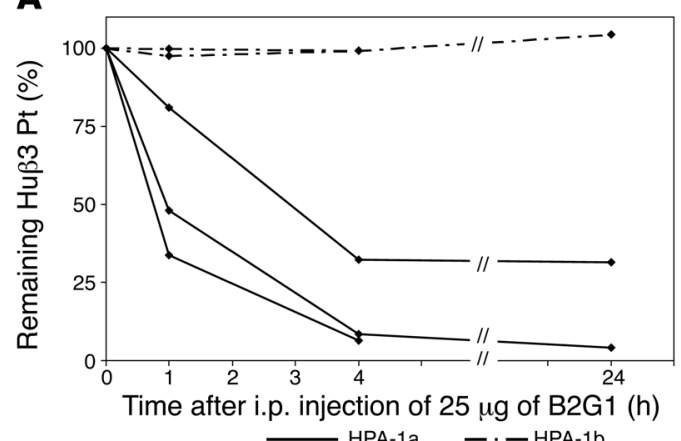

B
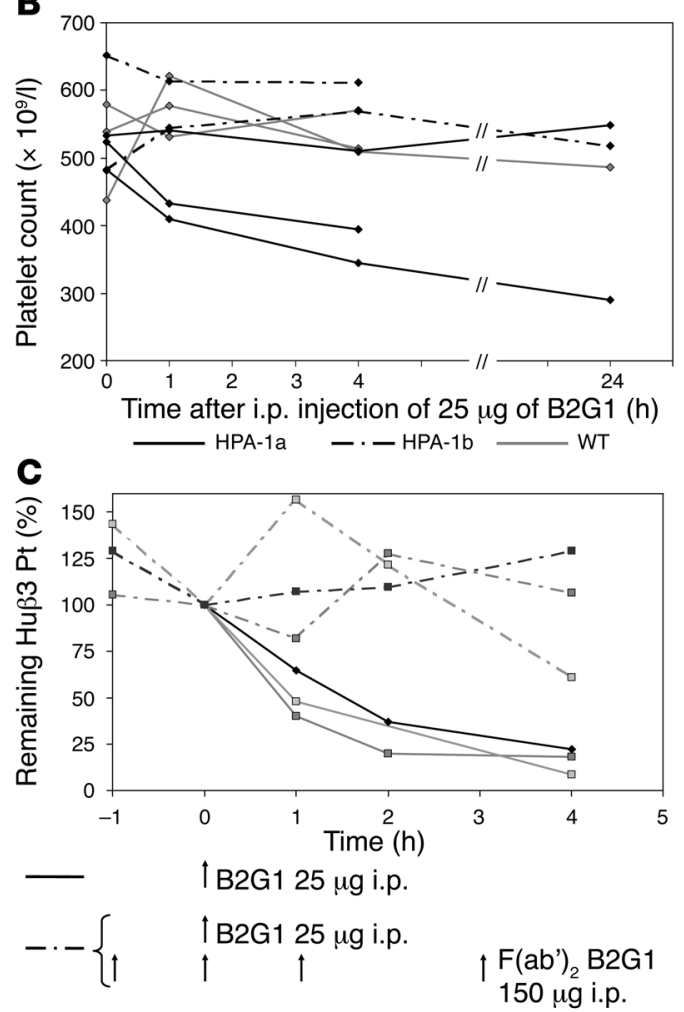

B2G1 necessary to achieve this correlated with the polyclonal anti-HPA-1a potencies and was consistent with the results obtained in the in vitro competition studies.

These results would support studies in human subjects to address safety, efficacy, and dose. In terms of safety, we have already shown that the $\mathrm{B} 2$ series of antibodies have no significant adverse effects on platelet activation and function (50). HPA-1a antibodies also bind to endothelial cells $\alpha v \beta 3$, but there is published evidence that B2G1 does not alter endothelial cell growth and activation status (51). Moreover, we have shown that ligand binding to $\alpha v \beta 3$ is unaffected in the presence of B2G1 (C. Ghevaert, unpublished observations). Finally, we have minimized the potential immunogenicity by the use of a fully human antibody and removal of the Gm allotypic residues.

With regard to efficacy, we have previously demonstrated improved intravascular survival in $\mathrm{RhD}$-positive healthy volunteers of autologous red cells sensitized with an RhD antibody containing the same $\Delta$ nab constant region compared with red cells sensitized with the parent IgG1 RhD antibody (52), showing that the

\section{Figure 6}

Platelet destruction studies with HPA-1a recombinant antibodies in the mice. $\beta 3^{--}$mice were transplanted with murine bone marrow transduced with the human $\beta 3$ integrin encoding with either Leu33 (HPA-1a) or Pro33 (HPA-1b). (A) The proportion of Huß3 Pt in 3 HPA-1a mice (solid lines) and 2 HPA-1b mice (dotted lines) after i.p. injection of $25 \mu \mathrm{g}$ B2G1. Huß3 Pt chimerism for each mouse at time 0 $(49 \%, 21 \%$, and $12 \%)$ corresponds to $100 \%$ Huß3 Pt on the graph. (B) Platelet counts in the 3 HPA-1a (solid lines), 2 HPA-1b (dotted lines), and $3 \mathrm{B3}^{-/-}$(gray lines) mice after $25 \mu \mathrm{g}$ B2G1 i.p. (C) The proportion of Huß3 Pt in 3 HPA-1a mice (baseline Huß3 Pt chimerism of $53 \%, 21 \%$, and $10 \%$ ) after i.p. injection of $25 \mu \mathrm{g} \mathrm{B2G1}$ alone (solid lines) and after $25 \mu \mathrm{g} \mathrm{B2G1}$ plus i.p. boluses of $150 \mu \mathrm{g} \mathrm{F}\left(\mathrm{ab}^{\prime}\right)_{2}$ B2G1 (dotted lines) at times shown.

encouraging results demonstrated in vitro in the CL assay translate to an in vivo protective effect in humans. Whether these results also apply to platelets sensitized with the modified anti-HPA-1a will be assessed in a forthcoming human volunteer study.

With regard to dosing, there is good evidence that in cases affected with anti-HPA-1a antibodies, ICH tends to occur only in fetuses with a platelet concentration of less than $20 \times 10^{9} / 1$ (18). Therefore, rather than restoring a normal platelet count, our aim with antenatal therapy should be to bring the fetal count into the absolutely safe zone of more than $50 \times 10^{9} / 1$. In hemolytic disease of the newborn, clinically significant hemolysis is associated with CL responses of more than $30 \%$ of the maximum response obtained with a control antibody (48). With HPA-1a antibodies, there appears to be no correlation between either in vitro potency or monocyte CL responses to maternal anti-HPA-1a and fetal platelet count (53). Therefore, at this stage it would be difficult to estimate by how much maternal antibodies would have to be blocked to generate a clinically significant effect. This particular question will have to be answered in clinical trials, where fetal blood sampling will be necessary to assess dose response. It is, however, possible to calculate the concentration of therapeutic antibody required to achieve a given degree of inhibition for each patient from the results of an in vitro competition assay, as demonstrated in the murine study. Whether the $15 \%$ intrinsic activity

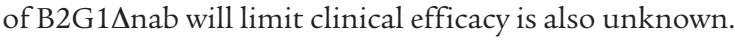

It is conceivable that the recombinant antibody could initially be assessed in patients undergoing therapy with serial IUTs, in whom the antibody could be administered straight into the fetal circulation, along with a platelet transfusion. The effect on the fetal platelet count and the requirement for further IUTs could then be assessed by serial fetal blood sampling in a similar fashion to current ongoing IVIG trials (26). The long-term aim, however, is to remove the risk of cordocentesis altogether by administering the antibody to the mother. We have already demonstrated that our Fc modifications do not abrogate placental transport (54) and binding to the placental transport receptor FcRn is unaffected.

Our in vitro data give some clues as to what concentration and total dose of antibody might be required for maternal administration. Assuming an adult plasma volume of 31 and equilibrium between maternal and fetal plasma, to reach a concentration of antibody capable of inhibiting $70 \%$ of binding and CL response as was achieved here would require between $30 \mathrm{mg}$ and $6 \mathrm{~g}$ of recombinant antibody. Such doses can be generated by recombinant technology, as shown by the dose of monoclonal anti-CD20 (rituximab) used for lymphoma therapy (55). Depending on the 
A

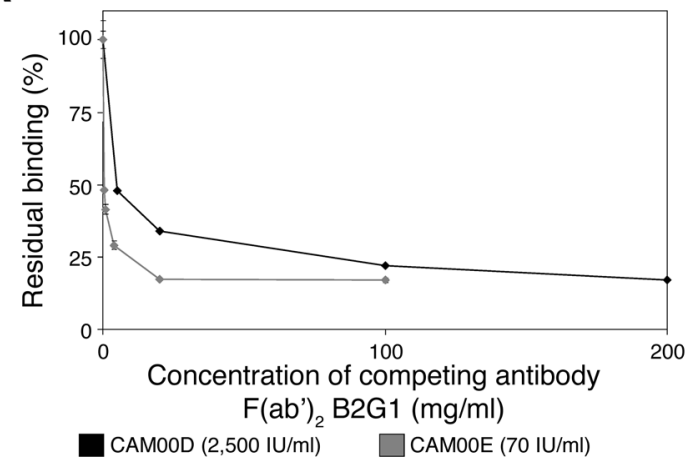

B
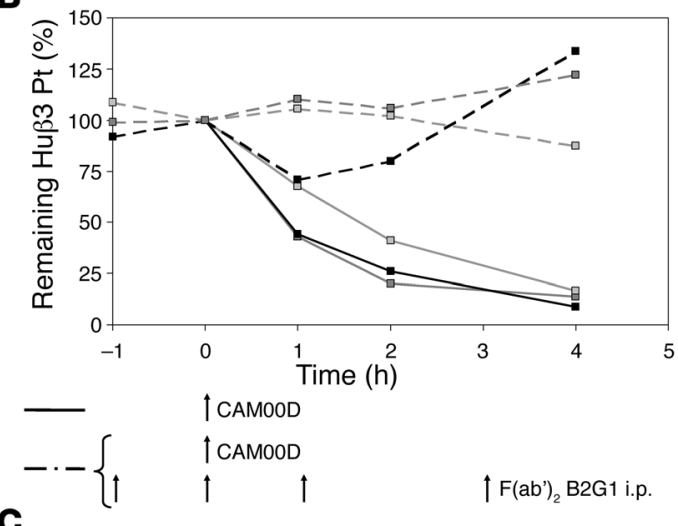

C

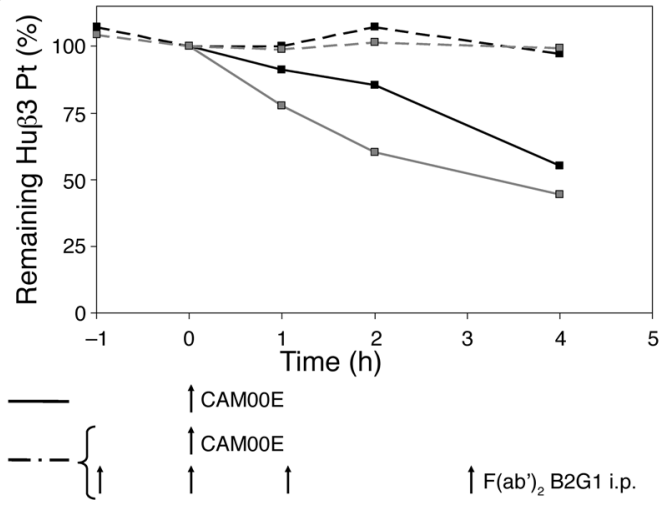

results of pharmacokinetic studies, multiple boluses of antibody may have to be administered repeatedly to protect from ICH from 16 weeks gestation until delivery.

In conclusion, this study has shown for what we believe to be the first time that it is possible to prevent binding of polyclonal sera to the HPA-1a epitope using a single recombinant high-affinity human antibody. We have shown that the modifications introduced in the constant region aimed at reducing binding to Fc $\gamma$ Rs substantially decrease monocyte response to platelets sensitized with the modified antibody and, furthermore, that monocyte responses to polyclonal HPA-1a antibodies can be abrogated by the nondestructive antibody. Finally, using a unique murine model, we have shown in proof of principle studies that in vivo platelet destruction by polyclonal antiHPA-1a can be prevented by a blocking antibody lacking a destructive constant region. Although the program of clinical evaluations will require extensive discussion with obstetricians and regulators, these results would support progression to human studies.

\section{Figure 7}

Platelet destruction studies in the murine model with polyclonal HPA-1a antibodies and $F\left(a b^{\prime}\right)_{2}$ B2G1. (A) Binding of the human polyclonal Ig anti-HPA-1a preparations CAMO0D and CAMO0E to HPA-1a heterozygous platelets by MAIPA in the presence of increasing concentrations of the $F\left(a b^{\prime}\right)_{2}$ fragment of B2G1. (B) The proportion of $\mathrm{Hu} 33 \mathrm{Pt}$ in $3 \mathrm{HPA}-1$ a mice (baseline Huß3 Pt chimerism of $49 \%, 60 \%$, and $34 \%)$ after i.p. injection of CAMOOD alone $(100 \mu \mathrm{l}$ for the first 2 mice and $10 \mu \mathrm{l}$ for the last one) (solid lines) and the proportion of $\mathrm{Hu} 33$ Pt in 3 HPA-1a mice (baseline Huß3 Pt chimerism of $67 \%, 83 \%$, and $22 \%$ ) after CAMOOD (100 $\mu \mathrm{l}$ for the first 2 mice; $10 \mu \mathrm{l}$ for the last one) plus i.p. boluses of $F\left(a b^{\prime}\right)_{2}$ B2G1 $(260,130,130$, and $130 \mu \mathrm{g}$ for the first 2 mice; 50, 25, 12.5, and $12.5 \mu \mathrm{g}$ for the last one) (dotted lines) at the times indicated. (C) The proportion of Huß3 Pt in $2 \mathrm{HPA}-1$ a mice (baseline Huß3 Pt chimerism of $26 \%$ and $21 \%$ ) after i.p. injection of $200 \mathrm{ul}$ CAMOOE alone (solid lines) and after CAM00E plus i.p. boluses of $100,50,25$, and $25 \mu \mathrm{g} \mathrm{F}\left(\mathrm{ab}^{\prime}\right)_{2}$ B2G1 (dotted lines) at times shown.

\section{Methods}

Production of recombinant HPA-1a antibodies. The generation of B2G1, a human IgG1 $\lambda$ version of an anti-HPA-1a single-chain $\mathrm{Fv}$, has been previously described (38), as has the vector containing the modified IgG1 gene, pSVgptFog1VHHuIgG1 $\Delta \mathrm{ab}$ (39). Briefly, IgG2 residues from positions 233-236 $(\Delta \mathrm{b})$ were substituted together with $\operatorname{IgG} 4$ residues 327,330 , and $331(\Delta \mathrm{a})$ into IgG1 to generate $\mathrm{G} 1 \Delta \mathrm{ab}$. The null allotype $(\Delta \mathrm{n})$ mutations (Lys214 to Thr, Asp356 to Glu, and Leu358 to Met) were introduced in this template by sequential overlap extension PCR, using Pwo DNA polymerase (Boehringer Mannheim) to generate the IgG1 $\Delta$ nab constant region gene which was cloned as a BamHI-NotI fragment into pSVgptB2VHHuIgG2 (38) to yield the vector pSVgptB2VHHuIgG1 1 nab. Thus the 2 full-length HPA-1 $\mathrm{a}$ antibodies generated for this study had the same $\mathrm{B} 2$ variable region and were designated "B2G1" and "B2G1 $\Delta$ nab."

For each antibody, the heavy-chain vector was cotransfected with the B2 $\lambda$-chain expression vector (38) into a rat myeloma cell line, YB2/0, and stable transfectants secreting the highest levels of antibody were isolated as previously described (39). Cell culture supernatant containing monoclonal antibody IgG was passed through a $0.22-\mu \mathrm{m}$ filter and IgG purified using a 5-ml Protein G Sepharose 4 Fast Flow column (Pharmacia). Protein Gbound material was eluted by using $0.1 \mathrm{M}$ glycine, $\mathrm{pH} 2.7$, then mixed with $12 \mu \mathrm{l} / \mathrm{ml} 5 \mathrm{M} \mathrm{NaCl}$ and $30 \mu \mathrm{l} / \mathrm{ml} 1 \mathrm{M}$ Tris buffer, $\mathrm{pH} 9$, to ensure isotonicity at $\mathrm{pH}$ 7.0. Purity of IgG was confirmed using a 3\%-5\% gradient sodium dodecyl sulphate polyacrylamide gel electrophoresis under nonreducing conditions as previously described (56).

Patients' sera. Twenty maternal sera taken at delivery from FMAIT cases and shown by the MAIPA assay to contain HPA-1a antibodies were retrieved from the serum bank at the Cambridge Blood Centre, meeting national requirements for patient consent. The sera were categorized by neonatal outcome (Table 1): (a) Anti-HPA-1a alone and ICH $(n=7)$; (b) anti-HPA-1a alone and neonatal platelet count of less than $50 \times 10^{9} / 1$ without ICH $(n=7)$; (c) anti-HPA-1a alone and platelet count of greater than $100 \times 10^{9} / 1$ at birth with a previously affected pregnancy and a homozygous partner $(n=4)$; and (d) anti-HPA-1a and anti-HPA-5b with platelet counts of $5 \times 10^{9}$ and $19 \times 10^{9} / 1$, respectively $(n=2)$.

Serum samples from 2 FMAIT cases with anti-HPA-1a and neonatal platelet counts of $2 \times 10^{9}$ and $13 \times 10^{9} / 1$ were used to generate 2 polyclonal IgG preparations (CAM00D and CAM00E) for the mouse studies. The HPA- $1 \mathrm{a}$ antibodies in the maternal serum samples were isolated by alloabsorption onto platelets from an apheresis HPA-1a homozygote donation (NHS Blood and Transplant) washed in PBS containing 0.2\% BSA (SigmaAldrich) $5 \mathrm{mM}$ EDTA (PBS/BSA/EDTA). Following elution with $76 \mathrm{mM}$ citric acid, $93 \mathrm{mM} \mathrm{NaCl}, 7 \mathrm{mM} \mathrm{Na}_{2} \mathrm{HPO}_{4}, 7 \mathrm{mM} \mathrm{NaH}_{2} \mathrm{PO}_{4}, \mathrm{pH} \mathrm{2.8}$, and 
neutralization with $214 \mathrm{mM}$ TRIS, $22 \mathrm{mM} \mathrm{Na}_{2} \mathrm{HPO}_{4}$, each sample was dialyzed in PBS using a 12- to $14-\mathrm{kDa}$ membrane (Medicell International $\mathrm{Ltd}$.). The IgG fraction was purified using a protein $\mathrm{G}$ column as described above, concentrated by centrifugation in $10-\mathrm{kDa}$ Vivaspin tubes (Sartorius) and passed through a $0.2-\mu \mathrm{m}$ filter.

Platelet immunofluorescence assay. Cryopreserved HPA-1a1a and -1b1b genotyped platelets (57) were thawed and resuspended in PBS/BSA/EDTA at a concentration of $50 \times 10^{9} / \mathrm{l}$. Platelet suspension $(50 \mu \mathrm{l})$ were sensitized with each recombinant antibody, washed, and incubated with a FITC-labeled rabbit anti-human Ig antibody (Dako). Data were analyzed using a Beckman Coulter XL-MCL flow cytometer.

MAIPA assay. The MAIPA assay was performed as described before (53) using cryopreserved HPA- $1 \mathrm{a} 1 \mathrm{~b}$ and HPA- $1 \mathrm{~b} 1 \mathrm{~b}$ platelets, the murine capture antibody NBS-PAB-1 (International Blood Group Reference Laboratory), and microtiter plates coated with a goat anti-mouse antibody (Jackson ImmunoResearch Laboratories). Bound human IgG was detected with a HRP-conjugated goat anti-human Fcy antibody (Jackson ImmunoResearch Laboratories). Each assay was performed in duplicate, and an average of the absorbance at $490 \mathrm{~nm}(\mathrm{OD})$ was read on an MRX plate reader (Dynex Technologies).

The potency of each clinical sample and both polyclonal IgG preparations was measured using the international anti-HPA-1a potency standard 03/152 (100 IU/ml) (National Institute for Biological Standards and Control) $(53,58)$.

In the MAIPA assay, the $\mathrm{F}\left(\mathrm{ab}^{\prime}\right)_{2}$ fragment of $\mathrm{B} 2 \mathrm{G} 1$ (IBGRL) did not react with the detecting HRP-conjugated goat anti-human FCy (data not shown) and therefore could be used as a blocking antibody in competition studies in which increasing concentrations of $\mathrm{F}\left(\mathrm{ab}^{\prime}\right)_{2} \mathrm{~B} 2 \mathrm{G} 1$ were added to a fixed concentration of either the full-length recombinant HPA-1a antibodies B2G1 and B2G1 $\mathrm{nab}$ or polyclonal anti-HPA-1a pre-diluted so as to be on the linear part of the standard curve. The decrease in OD seen in these competition studies was presumed to be proportional to the reduction of the amount of full-length antibodies bound to the platelets. F $\left(\mathrm{ab}^{\prime}\right)_{2} \mathrm{~B} 2 \mathrm{G} 1$ in increasing concentrations and full-length anti-HPA-1a antibodies or maternal sera were added to the platelets concomitantly and the MAIPA assay performed as above. The concentrations of $\mathrm{F}\left(\mathrm{ab}^{\prime}\right)_{2} \mathrm{~B} 2 \mathrm{G} 1$ that inhibited binding by $50 \%, 70 \%$, and the maximum amount achievable were calculated. The values obtained were then multiplied by the dilution factor to be able to compare each maternal serum undiluted.

Monocyte CL. The monocyte CL assay has been described before (53). Briefly, monocytes were prepared from pooled whole blood samples from 6 random donors (40), resuspended in HBSS, 20\% RPMI (Sigma-Aldrich), $2 \%$ FCS (HBSS/RPMI/FCS) $\left(3 \times 10^{8} / 1\right)$, and left to incubate in white flatbottomed 96-well plates (Optiplate-TM 96; PerkinElmer) for 2 hours at $37^{\circ} \mathrm{C}$ in a humidified atmosphere of $5 \% \mathrm{CO}_{2}$. Cryopreserved HPA-1a1b platelets were thawed and sensitized with the recombinant antibodies or the clinical samples. After washing the excess antibody, $50 \mu \mathrm{l}$ of sensitized platelets $\left(200 \times 10^{9} / \mathrm{l}\right)$ and $50 \mu \mathrm{l}$ of pre-warmed $4-\mathrm{mM}$ luminol $\left(37^{\circ} \mathrm{C}\right)$ were added to each well and $\mathrm{CL}$ was recorded at $37^{\circ} \mathrm{C}$ using a PolarstarGalaxy (BMG), taking 1-s measurements every $2.35 \mathrm{~min}$ for a total of 20 cycles (47 min). Platelets incubated with a human IgG1 anti-varicella zoster (VAZO-5; IBGRL) were used as a negative control. The CL signal for each patient was calculated as previously described as the total CL response (area under the curve) obtained over the 20 cycles expressed as a percentage of the response obtained with a positive control (B2G1 $10 \mu \mathrm{g} / \mathrm{ml})(53)$.
For the competition studies, platelets were sensitized with patients' sera or B2G1 $10 \mu \mathrm{g} / \mathrm{ml}$ and increasing concentrations of B2G1 $\Delta \mathrm{nab}$ and the CL assay performed as described above.

Mice studies. Animal studies complied with institutional guidelines and were approved by the Animal Care and Use Committee of the Medical College of Wisconsin's American Association for the Accreditation of Laboratory Animal Care-approved Biomedical Resource Center. The expression of the complex murine $\alpha \mathrm{IIb} /$ human $\beta 3$ in $\beta 3^{-/-}$mice has been described previously (42). Expression of human $\beta 3$ by murine platelets was measured by flow cytometry in a whole blood assay using the PE-labeled human $\beta 3$ specific antibody VI-PL2 (BD Biosciences) and the HPA phenotype assessed using FITC-labeled B2G1 (IBGRL). Mice were anesthetized with an inhalation anesthetic, and blood $(25 \mu \mathrm{l})$ was collected by tail-vein bleed into a microtube containing $1.0 \mathrm{ml}$ of Tyrode's buffer with $0.13 \mathrm{M}$ sodium citrate anticoagulant and $1 \mu \mathrm{g}$ of prostaglandin E1 (Sigma-Aldrich), similar to a previously described protocol (42). Samples were then incubated for $30 \mathrm{~min}$ with PE- and/or FITC-conjugated antibodies, diluted with $750 \mu \mathrm{l}$ of buffer, and analyzed on a FACScan flow cytometer (Becton Dickinson). The data were analyzed with Win MDI software. A minimum of $2 \times 10^{4}$ events were collected from entities exhibiting forward- and side-scattering properties of murine blood platelets. A marker was set on the platelets from $\beta 3^{-/-}$mice, and the percentage of platelets giving a positive signal above this marker was considered to be the percentage of Huß3 Pt.

To assess the effect of recombinant anti-HPA-1a or polyclonal sera on platelet survival, mice were injected i.p. with the given dose of antibodies and tail bleeds were performed at the times indicated in the Figure 3 legend. Circulating platelet levels were measured from whole blood with an Animal Blood Counter (Oxford Science), and flow cytometry was used to calculate the proportion of $\mathrm{Hu} \beta 3 \mathrm{Pt}$ present in circulation. Given the difference between mouse and human Fc $\mathrm{R}$ profile (43), $\mathrm{F}\left(\mathrm{ab}^{\prime}\right)_{2}$ B2 G1 (which lacks a constant region altogether and therefore does not bind to either human or mouse Fc $\gamma$ R), rather than B2G1 $\mathrm{n}$ nab (whose constant region has been tailored to abrogate binding to human $F(\gamma R$ ), was used as a proof of principle protective antibody in competition studies. The $\mathrm{F}\left(\mathrm{ab}^{\prime}\right)_{2}$ was injected i.p. using different dosing schedules as described above.

\section{Acknowledgments}

We are grateful to Rosey Mushens (IBGRL) for cell culture and antibody purification and to the Platelet Immunology Reference Laboratory at the NHS Blood and Transplant for their help with the MAIPA assay. This work was supported by grants from the National Blood Service (to C. Ghevaert) and the NIH (HL68138, to D.A. Wilcox). The work was also supported by award R0168138 from the National Heart, Lung, and Blood Institute of the NIH. The content is solely the responsibility of the authors and does not necessarily represent the official views of the National Heart, Lung, and Blood Institute.

Received for publication December 10, 2007, and accepted in revised form May 21, 2008.

Address correspondence to: Cedric Ghevaert, Division of Transfusion Medicine, NHS Blood and Transplant, Long Road, Cambridge CB2 2PT, United Kingdom. Phone: 44-7712-179785; Fax: 44-1223-548136; E-mail: cedric.ghevaert@nhsbt.nhs.uk.
1. Burrows, R.F., and Kelton, J.G. 1993. Fetal thrombocytopenia and its relation to maternal thrombocytopenia. N. Engl. J. Med. 329:1463-1466.

2. Mueller-Eckhardt, C., et al. 1989. 348 cases of suspected neonatal alloimmune thrombocytopenia.
Lancet. 1:363-366.

3. Berry, J.E., et al. 2000. Detection of Gov system antibodies by MAIPA reveals an immunogenicity similar to the HPA-5 alloantigens. Br. J. Haematol. 110:735-742.
4. Davoren, A., Curtis, B.R., Aster, R.H., and McFarland, J.G. 2004. Human platelet antigen-specific alloantibodies implicated in 1162 cases of neonatal alloimmune thrombocytopenia. Transfusion. 44:1220-1225.

5. Williamson, L.M., et al. 1998. The natural history 
of fetomaternal alloimmunization to the plateletspecific antigen HPA-1a (PlA1, Zwa) as determined by antenatal screening. Blood. 92:2280-2287.

6. Jaegtvik, S., et al. 2000. Neonatal alloimmune thrombocytopenia due to anti-HPA $1 \mathrm{a}$ antibodies the level of maternal antibodies predicts the severity of thrombocytopenia in the newborn. BJOG. 107:691-694

7. Durand-Zaleski, I., et al. 1996. Screening primiparous women and newborns for fetal/neonatal alloimmune thrombocytopenia: a prospective comparison of effectiveness and costs. Immune Thrombocytopenia Working Group. Am.J. Perinatol. 13:423-431.

8. Dreyfus, M., et al. 1997. Frequency of immune thrombocytopenia in newborns: a prospective study. Immune Thrombocytopenia Working Group. Blood. 89:4402-4406.

9. Turner, M.L., et al. 2005. Prospective epidemiologic study of the outcome and cost-effectiveness of antenatal screening to detect neonatal alloimmune thrombocytopenia due to anti-HPA-1a. Transfusion. 45:1945-1956.

10. Kjeldsen-Kragh, J., et al. 2007. A screening and intervention program aimed to reduce mortality and serious morbidity associated with severe neonatal alloimmune thrombocytopenia. Blood. 110:833-839.

11. Giovangrandi, Y., et al. 1990. Very early intracranial haemorrhage in alloimmune fetal thrombocytopenia. Lancet. 336:310.

12. Murphy, M.F., et al. 1994. Antenatal management of fetomaternal alloimmune thrombocytopeniareport of 15 affected pregnancies. Transfus. Med. 4:281-292.

13. Engelfriet, C.P., et al. 2003. Prenatal management of alloimmune thrombocytopenia of the fetus. Vox. Sang. 84:142-149.

14. Ranasinghe, E., et al. 2001. Provision of platelet support for fetuses and neonates affected by severe fetomaternal alloimmune thrombocytopenia. Br.J. Haematol. 113:40-42.

15. Overton, T.G., Duncan, K.R., Jolly, M., Letsky, E., and Fisk, N.M. 2002. Serial aggressive platelet transfusion for fetal alloimmune thrombocytopenia: platelet dynamics and perinatal outcome. Am. J. Obstet. Gynecol. 186:826-831.

16. Buscaglia, M., et al. 1996. Percutaneous umbilical blood sampling: indication changes and procedure loss rate in a nine years' experience. Fetal Diagn.Ther 11:106-113.

17. Paidas, M.J., et al. 1995. Alloimmune thrombocytopenia: fetal and neonatal losses related to cordocentesis. Am. J. Obstet. Gynecol. 172:475-479.

18. Ghevaert, C., et al. 2007. Management and outcome of 200 cases of fetomaternal alloimmune thrombocytopenia. Transfusion. 47:901-910.

19. Bussel, J.B., et al. 1996. Antenatal management of alloimmune thrombocytopenia with intravenous gamma-globulin: a randomized trial of the addition of low-dose steroid to intravenous gammaglobulin. Am. J. Obstet. Gynecol. 174:1414-1423.

20. Berkowitz, R.L., et al. 2006. Parallel randomized trials of risk-based therapy for fetal alloimmune thrombocytopenia. Obstet. Gynecol. 107:91-96.

21. Kaplan, C., Murphy, M.F., Kroll, H., and Waters, A.H. 1998. Feto-maternal alloimmune thrombocytopenia: antenatal therapy with IvIgG and steroids-more questions than answers. European Working Group on FMAIT. Br. J. Haematol. 100:62-65.

22. Birchall, J.E., Murphy, M.F., Kaplan, C., and Kroll, H. 2003. European collaborative study of the antenatal management of feto-maternal alloimmune thrombocytopenia. Br. J. Haematol. 122:275-288.

23. Radder, C.M., Brand, A., and Kanhai, H.H. 2001. A less invasive treatment strategy to prevent intracranial hemorrhage in fetal and neonatal alloimmune thrombocytopenia. Am. J. Obstet. Gynecol. 185:683-688

24. Kanhai, H.H., van den Akker, E.S., Walther, F.J., and Brand, A. 2006. Intravenous immunoglobulins without initial and follow-up cordocentesis in alloimmune fetal and neonatal thrombocytopenia at high risk for intracranial hemorrhage. Fetal Diagn. Ther. 21:55-60.

25. Kroll, H., et al. 1994. Maternal intravenous immunoglobulin treatment does not prevent intracranial haemorrhage in fetal alloimmune thrombocytopenia. Transfus. Med. 4:293-296.

26. Berkowitz, R.L., Bussel, J.B., and McFarland, J.G. 2006. Alloimmune thrombocytopenia: state of the art 2006. Am. J. Obstet. Gynecol. 195:907-913.

27. El Shanawany, T., and Jolles, S. 2007. Intravenous immunoglobulin and autoimmune disease. Ann. N.Y. Acad. Sci. 1110:507-515.

28. Power, J.P., et al. 1995. Hepatitis C infection from anti-D immunoglobulin. Lancet. 346:372-373.

29. Smith, D.B., et al. 1999. A second outbreak of hepatitis $\mathrm{C}$ virus infection from anti-D immunoglobulin in Ireland. Vox Sang. 76:175-180.

30. Ironside, J.W. 2006. Variant Creutzfeldt-Jakob disease: risk of transmission by blood transfusion and blood therapies. Haemophilia. 12(Suppl. 1):8-15.

31. Pendergrast, J.M., Sher, G.D., and Callum, J.L. 2005 Changes in intravenous immunoglobulin prescribing patterns during a period of severe product shortages, 1995-2000. Vox Sang. 89:150-160.

32. Bayry, J., Kazatchkine, M.D., and Kaveri, S.V. 2007. Shortage of human intravenous immunoglobulin - reasons and possible solutions. Nat. Clin. Pract. Neurol. 3:120-121.

33. Goldberger, A., Kolodziej, M., Poncz, M., Bennett, J.S., and Newman, P.J. 1991. Effect of single amino acid substitutions on the formation of the PIA and Bak alloantigenic epitopes. Blood. 78:681-687.

34. Greenwood, J., and Clark, M.R. 1993. Protein engineering of antibody molecules for prophylactic and therapeutic applications in man. Academic Titles. Nottingham, United Kingdom. 85-100.

35. Firan, M., et al. 2001. The MHC class I-related receptor, FcRn, plays an essential role in the maternofetal transfer of gamma-globulin in humans. Int Immunol. 13:993-1002.

36. Griffin, H.M., and Ouwehand, W.H. 1995. A human monoclonal antibody specific for the leucine-33 (P1A1, HPA-1a) form of platelet glycoprotein IIIa from a $\mathrm{V}$ gene phage display library. Blood 86:4430-4436

37. Santoso, S., et al. 2006. A naturally occurring LeuVal mutation in beta3-integrin impairs the HPA-1a epitope: the third allele of HPA-1. Transfusion. 46:790-799.

38. Garner, S.F., et al. 2000. A rapid one-stage wholeblood HPA-1a phenotyping assay using a recombinant monoclonal IgG1 anti-HPA-1a. Br. J. Haematol. 108:440-447.

39. Armour, K.L., Clark, M.R., Hadley, A.G., and Williamson, L.M. 1999. Recombinant human IgG molecules lacking Fcgamma receptor I binding and monocyte triggering activities. Eur. J. Immunol. 29:2613-2624.

40. Turner, C.P., and Hadley, A.G. 2003. The role of P-selectin in the immune destruction of platelets. Br. J. Haematol. 121:623-631.

41. Ni, H., et al. 2006. A novel murine model of fetal and neonatal alloimmune thrombocytopenia: response to intravenous IgG therapy. Blood. 107:2976-2983.

42. Fang, J., et al. 2005. Therapeutic expression of the platelet-specific integrin, alphaIIbbeta3, in a murine model for Glanzmann thrombasthenia. Blood. 106:2671-2679

43. Mestas, J., and Hughes, C.C. 2004. Of mice and not men: differences between mouse and human immunology. J. Immunol. 172:2731-2738.

44. Bye, J.M., et al. 1992. Germline variable region gene segment derivation of human monoclonal anti$\mathrm{Rh}(\mathrm{D})$ antibodies. Evidence for affinity maturation by somatic hypermutation and repertoire shift. J. Clin. Invest. 90:2481-2490.

45. Valentin, N., Visentin, G.P., and Newman, P.J. 1995. Involvement of the cysteine-rich domain of glycoprotein IIIa in the expression of the human platelet alloantigen, PlA1: evidence for heterogeneity in the humoral response. Blood. 85:3028-3033.

46. Stafford, P., et al. 2008. Immunologic and structural analysis of eight novel domain-deletion beta3 integrin peptides designed for detection of HPA-1 antibodies. J. Thromb. Haemost. 6:366-375.

47. Armour, K.L., van de Winkel, J.G., Williamson, L.M., and Clark, M.R. 2003. Differential binding to human FcgammaRIIa and FcgammaRIIb receptors by human IgG wildtype and mutant antibodies. Mol. Immunol. 40:585-593.

48. Hadley, A.G., et al. 1998. The ability of the chemiluminescence test to predict clinical outcome and the necessity for amniocenteses in pregnancies at risk of haemolytic disease of the newborn. Br. J. Obstet. Gynaecol. 105:231-234.

49. Isaacs, J.D., Clark, M.R., Greenwood, J., and Waldmann, H. 1992. Therapy with monoclonal antibodies. An in vivo model for the assessment of therapeutic potential. J. Immunol. 148:3062-3071.

50. Joutsi-Korhonen, L., et al. 2004. The effect of recombinant IgG antibodies against the leucine33 form of the platelet beta3 integrin (HPA-1a) on platelet function. Thromb. Haemost. 91:743-754.

51. Radder, C.M., Beekhuizen, H., Kanhai, H.H., and Brand, A. 2004. Effect of maternal anti-HPA-1a antibodies and polyclonal IVIG on the activation status of vascular endothelial cells. Clin. Exp. Immunol. 137:216-222.

52. Armour, K.L., et al. 2006. Intravascular survival of red cells coated with a mutated human anti-D antibody engineered to lack destructive activity. Blood. 107:2619-2626

53. Ghevaert, C., et al. 2007. HPA-1a antibody potency and bioactivity do not predict severity of fetomaternal alloimmune thrombocytopenia. Transfusion. 47:1296-1305

54. Armstrong-Fisher, S., et al. 2004. In vitro maternofetal transfer of native and $\mathrm{FC}_{\mathrm{C}}$ mutated recombinant antibodies. Vox Sang. 87(Suppl. 3):37.

55. Fanale, M.A., and Younes, A. 2007. Monoclonal antibodies in the treatment of non-Hodgkin's lymphoma. Drugs. 67:333-350.

56. Laemmli, U.K. 1970. Cleavage of structural proteins during the assembly of the head of bacteriophage T4. Nature. 227:680-685.

57. Bugert, P., et al. 2005. Microarray-based genotyping for blood groups: comparison of gene array and 5 '-nuclease assay techniques with human platelet antigen as a model. Transfusion. 45:654-659.

58. Allen, D., et al. 2005. Collaborative study to establish the first international standard for quantitation of anti-HPA-1a. Vox Sang. 89:100-104.

59. Clark, M.R. 1997. IgG effector mechanisms. Chem. Immunol. 65:88-110. 